\title{
Regulating Ecosystem Service (Filtering/ Immobilization of Inorganic Pollutants) Supplied by Soil in Model Regions of Slovakia
}

\author{
Jarmila Makovníková1, Boris Pálka1, Miloš Širáň ${ }^{1}$, Stanislav Kološta² \\ ${ }^{1}$ National Agricultural and Food Centre/Soil Science and Conservation Research Institute Bratislava, Regional Station, Banská \\ Bystica, Slovakia \\ ${ }^{2}$ Faculty of Economics, Matej Bel University in Banská Bystrica, Banská Bystrica, Slovakia \\ Email: jarmila.makovnikova@nppc.sk
}

How to cite this paper: Makovníková, J., Pálka, B., Širáń, M., \& Kološta, S. (2021). Regulating Ecosystem Service (Filtering/ Immobilization of Inorganic Pollutants) Supplied by Soil in Model Regions of Slovakia. Journal of Geoscience and Environment Protection, 9, 61-72.

https://doi.org/10.4236/gep.2021.911005

Received: October 5, 2021

Accepted: November 16, 2021

Published: November 19, 2021

Copyright $\odot 2021$ by author(s) and Scientific Research Publishing Inc. This work is licensed under the Creative Commons Attribution International License (CC BY 4.0).

http://creativecommons.org/licenses/by/4.0/

\begin{abstract}
The immobilization of soil contaminants (as one of the regulating ecosystem services) plays very important role in environment. This regulatory service prevents groundwater contamination and the entry of contaminants into the food chain. The evaluation as well as the spatial distribution of this regulatory service is important for optimal land management in a specific region. Mapping system combining input layers-slope topography, soil texture, climate region and land use (arable land, grassland)-were created for the analysis and the evaluation of potential of agroecosystem services. Filtering potential was calculated as accumulative function of soil sorption potential and potential of total content of inorganic pollutants evaluated according to The Slovak Soil Law. Calculated potential was categorised into five categories: very low, low, medium, high and very high. Four model areas were selected for the analysis of pollutant filtration, as one of the regulatory agroecosystem services, which are located in different climatic areas and different soil-ecological conditions of Slovakia. The greatest differences among model regions can be found in relation to climatic conditions, land use and diversity of soil types. The warm, dry, and lowland region has a higher potential for pollutant filtration than the moderately warm or cold region. These results are consistent with the location of the soil, its properties, processes and functions within the concept of agro-ecosystem services. Based on the results, we can state that the high risk of inorganic contaminants is inherent in soils with low content and quality of organic substances, low $\mathrm{pH}$ value and high concentration of contaminants.
\end{abstract}

\section{Keywords}

Filtering Ecosystem Service, Inorganic Contaminants, Soil Sorbents 


\section{Introduction}

Agroecosystem services are the multiple goods and services provided to humankind by nature (Dominati, 2013; Burkhard, \& Maes, 2017) in combination with additional anthropogenic inputs in agricultural systems. Regulating services are defined as the benefits obtained from the regulation of ecosystem processes, including the regulation of climate, water, and some human diseases (MEA, 2005). All these services are not directly consumed by people as goods, but regulating services also bringing many direct benefits in form of keeping safe and habitable environments, supporting food production systems or processing and removing waste and pollution (Dominati, 2013; Burkhard, \& Maes, 2017). According to Dominati (2013), water regime regulation, soil erosion control, climate regulation and soil pollutant filtration belong to the main regulatory services in agroecosystems.

Inorganic contaminants, mainly potential risk elements, are serious problem in all environmental compartments. Inorganic contaminants negatively affect the health of the agroecosystem, the production of agricultural land as well as human health (Ahmad et al., 2021). Inorganic contaminants reduce soil fertility, soil biodiversity, nitrogen fixation, increase erodibility, affect larger loss of soil and nutrients, reduce crop yield, and affect imbalance in soil and flora (Campo, 2017; Houšková et al., 2021). The sources of heavy metal contamination of soil include atmospheric deposition (e.g. from fossil fuel combustion), organic and mineral fertilisers and lime, pesticides, sludge, and waste material from household and industry (e.g. metallurgical). In addition, all soils have a natural content of heavy metals inherent from the parent material. Background levels of soil elements depend on both, the nature of the parent materials and the soil texture since many elements are associated with the fine particles which have the ability to adsorb or form solid solutions with the element of interest (Naidu et al., 1996).

The immobilization of soil contaminants (as one of the regulating ecosystem services) plays very important role in assessment the soil function. The soil processes, which control the fate and distribution of heavy metals and metalloids in the terrestrial environment, include several fundamental physical, chemical and biological processes. Immobilisation of the soil contaminants means ability of soil to keep substances and prevent them from leaching and contamination of groundwater, or entrance into the food chain (Yong et al., 1992). It allows leaching (chemicals may be transported through the soil by solvents as water or with soil movement) and runoff (a movement to contaminate air, water, soil, plants and animals, as well as chemical moving across a surface with a solvent or with the soil). The filtering capacity of soil refers to its ability to retain contaminants bonding them with varying intensity (from weak to strong) to organic or mineral soil constituents, and thereby preventing their release into water passing through the soil profile (Boruvka \& Drabek, 2004; Burkhard \& Maes, 2017). Soil $\mathrm{pH}$, together with organic matter, is one of the most important soil parameters 
that affect the bioavailability of elements in the soil (Yong et al., 1992; Naidu, 1996; Makovníková et al., 2007; Makovníková \& Barančíková, 2009). This phenomenon is related to soil sorbents charges depending on the value of soil reaction. At low $\mathrm{pH}$, the sorption of potential risk elements is also relatively low with respect to competition of adsorbing sites by proton $\left(\mathrm{H}^{+}\right)$. Inappropriate land management can lead to land degradation and thus can reduce the provision of all agroecosystem services (Dendoncker et al., 2018). However, in the present widespread scenario of multiple problems including land degradation and land pollution, there is a need to study regulating services in an objective manner, including soil filtration.

Techniques that are often used to evaluate and map ecosystem services are expert-based estimations, expert-scoring, implementing land use classes and land use cover (Burkhard et al., 2009) or participatory GIS mapping (Maes et al., 2018). The concept of natural capital and agroecosystem services are widely accepted and their potential contribution to better environmental management is also acknowledged (MEA, 2005). However, their practical applications such as distribution and mapping are still insufficient and limited. Biophysical indicators (soil quality indicators) as well as localization and changes over space and time due to human induced land cover and land use are used by many authors to evaluate ecosystem services (Alam et al., 2016; Dominati et al., 2010). The quantification and mapping of ecosystem services distribution is considered as one of the main requirements for the implementation of the concept of ecosystem services into institutional decision-making. However, in the present widespread scenario of multiple problems including land pollution, there is a need of addressing regulating service (immobilization of pollutants) for a specific region, in an objective manner. This is only possible by linking its assessment with spatial mapping system, which we designed for Slovakia.

The aim of this study was to evaluate and map one of the regulating agroecosystem service (filtration potential for inorganic pollutants/immobilization) supplied by soil in different climatic regions of Slovakia.

\section{Material and Method}

\subsection{Evaluation of Filtering Potential for Soil Pollutants}

Filtering potential for soil pollutants (as one of the regulating agroecosystem services) was determined from actual state of soil contamination and the potential of soil sorbents that are sensitive to the sorption of risk elements (potentially toxic elements as $\mathrm{Hg}, \mathrm{Pb}$ and $\mathrm{Cd}$; essential important elements in optimal concentration range as $\mathrm{Cu}, \mathrm{Ni}, \mathrm{Mn}, \mathrm{Zn}, \mathrm{Co}, \mathrm{Cr}, \mathrm{Se}$ ). The subject of our study was the group of risk contaminants in total.

Filtering potential was calculated according to Equation (1).

FP $($ Filtering Potential $)=$ SP $($ Sorption Potential of soil $)+K$

where $\mathrm{K}-$ Potential of total content of inorganic contaminants was evaluated 
according to The Slovak Law No. 220/2004.

The evaluation of Sorption Potential of soil (SP) was calculated as a sum of quality factors ( $\mathrm{pH}, \mathrm{Q}_{4}{ }^{6}$ ) and quantity factors (Cox, H-depth of humus horizon) according to Equation (2):

$$
\mathrm{SP}=\mathrm{F}(\mathrm{pH})+\mathrm{F}(\mathrm{Q} 46)+\mathrm{F}(\mathrm{Cox}) * \mathrm{~F}(\mathrm{H})
$$

This method is described in detail in our previous article Makovníková et al. (2007).

Based on the point evaluation of input parameters, the summary values were categorised into five categories: 1) very low relevant capacity, 2) low relevant capacity, 3) medium relevant capacity, 4) high relevant capacity, and 5) very high relevant capacity.

\subsection{Mapping the Filtering Potential}

The mapping of regular grid (one cell of $100 \mathrm{~m}$ resolution) was created by combining four input layers: 1) climatic region (categories: moderately cold, moderately warm, warm and very warm), 2) slope topography (categories: $0^{\circ}-2^{\circ}, 2.1^{\circ}$ $-5^{\circ}, 5.1^{\circ}-12^{\circ}$ and more than $12^{\circ}$ ), 3) soil texture (categories: soil particles < $0.01 \mathrm{~mm}$ less than 20\%, 20\% - 45\%, more than 45\%), and 4) land use (arable land, grassland and other cultures like sets, vineyards, hops). This regular grid is compatible with the spatial units in international database Corine Land Cover. For better explanation, we divided the total layer of agricultural land on the basis of possible combinations of the above mentioned layers into 100 mapping units and each of these mapping units has its ecosystem service value based on the evaluated soil parameters. The resulting values of immobilization potential were converted into spatial mapping units of $100 \times 100 \mathrm{~m}$. We then calculated the weighted average for the individual mapping units (from all mapping units that belong to a model regions). Software package of the geographic information system $\operatorname{ArcGIS}^{\circledR}$ was used for processing the input geo-referenced digital data and the resulting maps.

For the analysis of pollutant filtration (as one of the regulatory agroecosystem services), four model areas located in different climatic areas and different soil-ecological conditions were selected reflecting the diversity and possibilities the natural capital usage in Slovakia (model regions illustrates Figure 1: Krupina, Michalovce, Pieštany and Brezno).

\section{Michalovce region}

Part of the East Slovak lowland (Figure 1) which is homogeneous in height, with a predominantly warm (99.4\% of the area) to moderately warm climate with the area of $1019.26 \mathrm{~km}^{2}$.

\section{Krupina region}

The location is in the south of central Slovakia (Figure 1) with an area of 548 $\mathrm{km}^{2}$. The climate varies mostly from very warm $(58.9 \%)$ to moderately warm (36.6\%).

Brezno region 


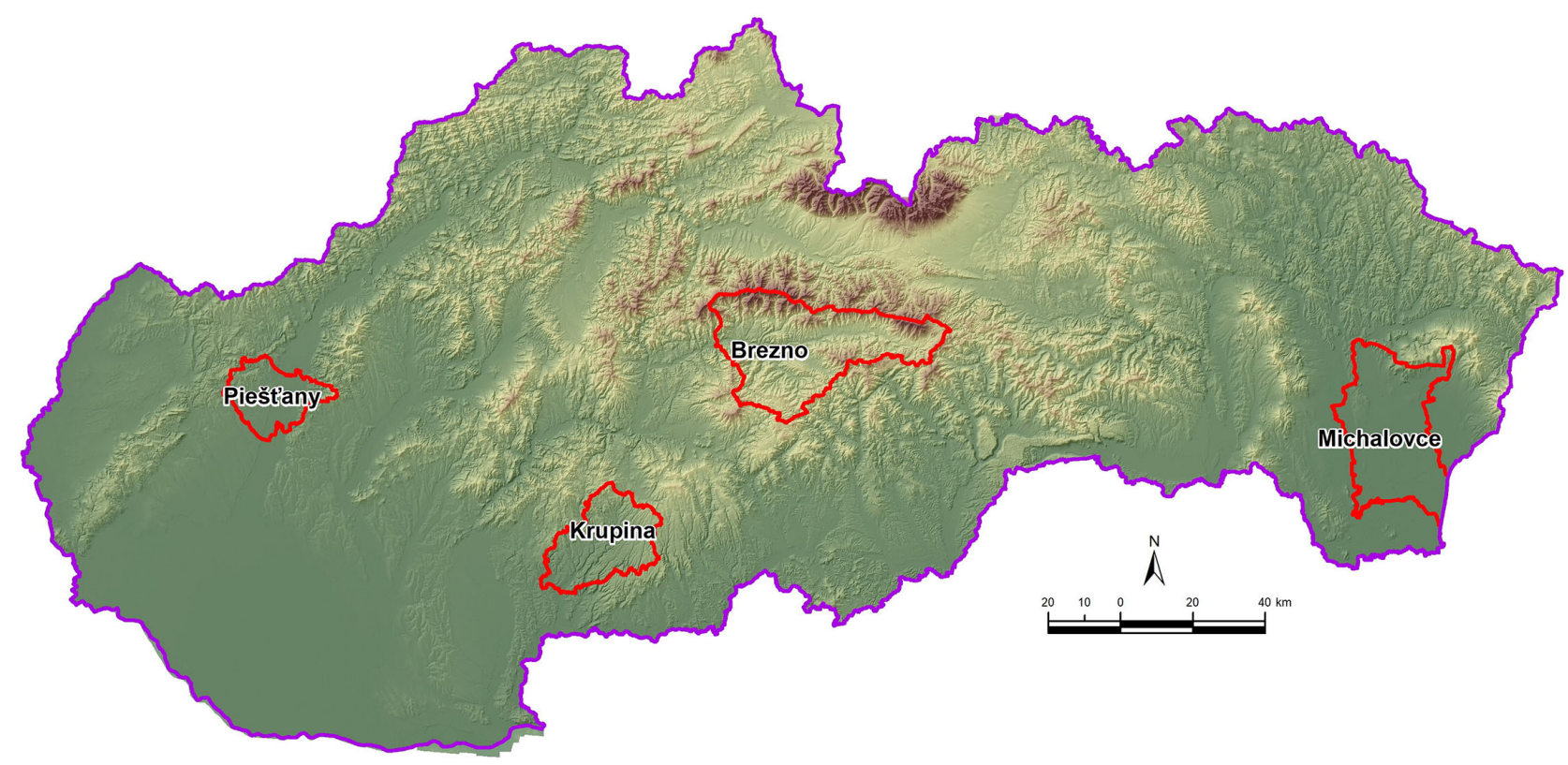

Figure 1. Geographical location of model regions.

The location is in the middle of central Slovakia (Figure 1). With an area of $1265 \mathrm{~km}^{2}$ is the sixth largest district in Slovakia. The majority of the district is located at an altitude of over 600 meters above sea level (88.6\%) with the lowest point at 406 meters above sea level. This is related to the predominance of cold climate ( $86.9 \%$ of the area).

\section{Pieštany region}

The location is in the south-western part of Slovakia with an area of 381.12 $\mathrm{km}^{2}$. The Pieštany model region is located on the northern edge of the Danubian Lowland in a part of the Trnava Uplands (Figure 1) with very warm climate in most of the region.

\subsection{Data Sources}

Data from the Geochemical Atlas of Soils of Slovakia, data from the Digital Soil Map of Slovakia and data of Soil Monitoring of Slovakia were used to evaluate the potential of total content of inorganic contaminants in soil and sorption potential of soil. The basis for a classification of agro-climatic regions were provided by the Information Service of the National Agricultural and Food Centre/Soil Science and Conservation Research Institute (NAFC-SSCRI, 2015), Land Parcel Identification System (LPIS) and Digital Soil Map of Slovakia.

\section{Results and Discussion}

The filtering potential of agroecosystems depends on two main factors, the total amount of potential risk elements in soil (risk element according to Decree 59/2013 of the Ministry of Industry and Trade of the Slovak Republic, which amends the Land Act No. 220/2004), and the potential of soil sorbents which are sensitive to the risk elements sorption. Soils have natural content of risk ele- 
ments released from parent rock in the process of pedogenesis, which can be increased by inputs of risk elements by anthropogenic deposition (Makovníková, 2001; Čurlík, 2011). Almost any soil has been affected by human activities, e.g. through atmospheric deposition. High potential for contamination reduces the filtering potential because the sorption sites are already occupied and thus the free sorption capacity, which can contribute to the immobilization of risk elements, is reduced (Makovniková et al., 2007; Makovníková \& Barančíková, 2009; Ryzhenko \& Kavetsky, 2015; Yong et al., 1992). Categories of filtering potential as $\%$ of used agricultural land in model regions are in Table 1.

The distribution of the filtering potential in model regions of Slovakia is illustrated in Figures 2-5.

Table 1. The filtering potential of agroecosystems in model regions.

\begin{tabular}{cccccc}
\hline \multirow{2}{*}{ Region } & \multicolumn{5}{c}{ Category of filtering potential in \% of used agricultural land } \\
\cline { 2 - 6 } & Very low & Low & Medium & High & Very high \\
\hline Michalovce & 0.19 & 79.89 & 19.92 & 0.00 & 0.00 \\
Krupina & 0.00 & 46.19 & 2.21 & 22.07 & 29.53 \\
Brezno & 30.22 & 65.83 & 3.95 & 0.00 & 0.00 \\
Pieštany & 0.00 & 0.51 & 0.06 & 12.16 & 87.27 \\
\hline
\end{tabular}

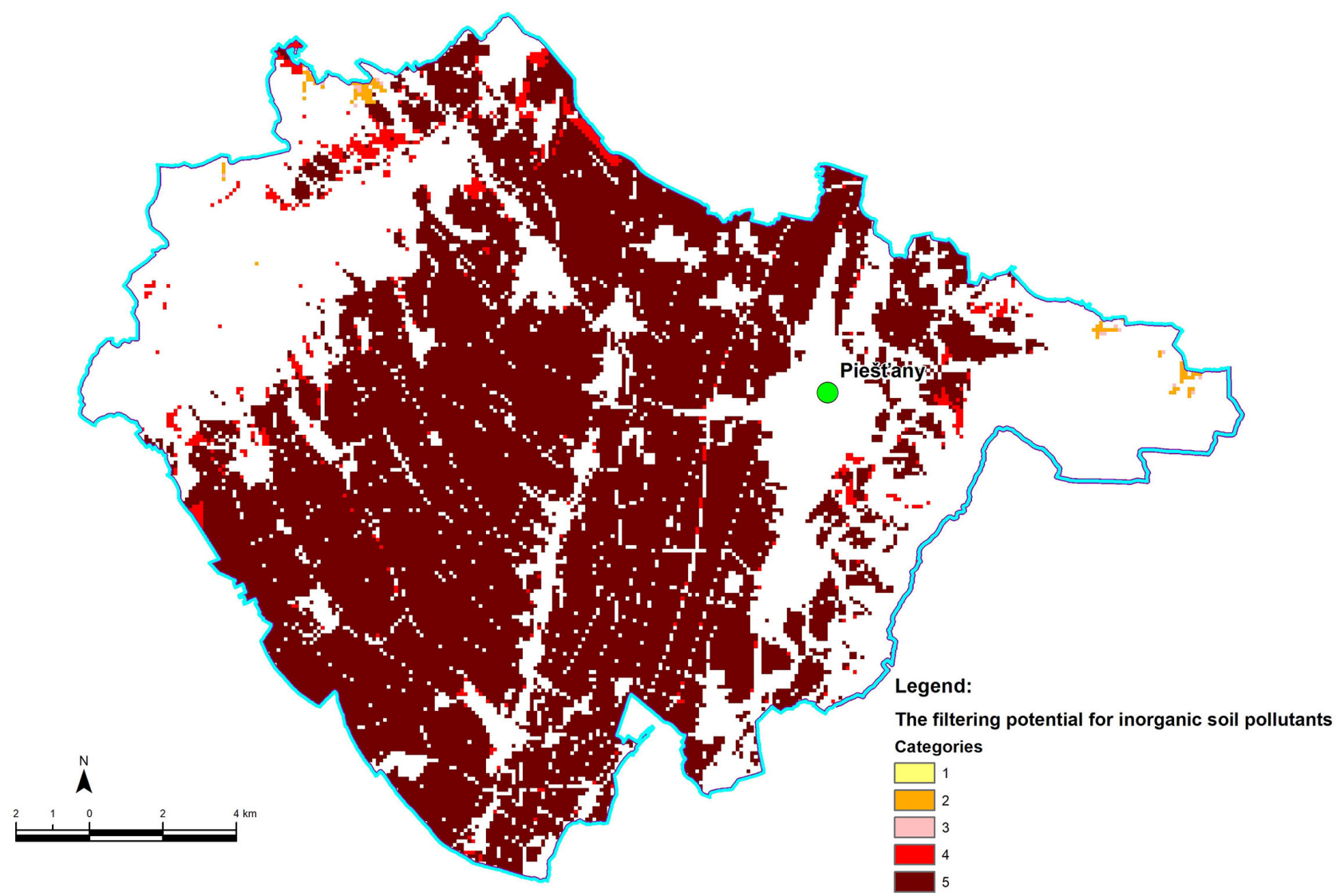

Figure 2. The filtering potential for inorganic soil pollutants in Pieštany region (authors: Makovníková J. and Pálka B.; green dot means localization of capital city of the region). 


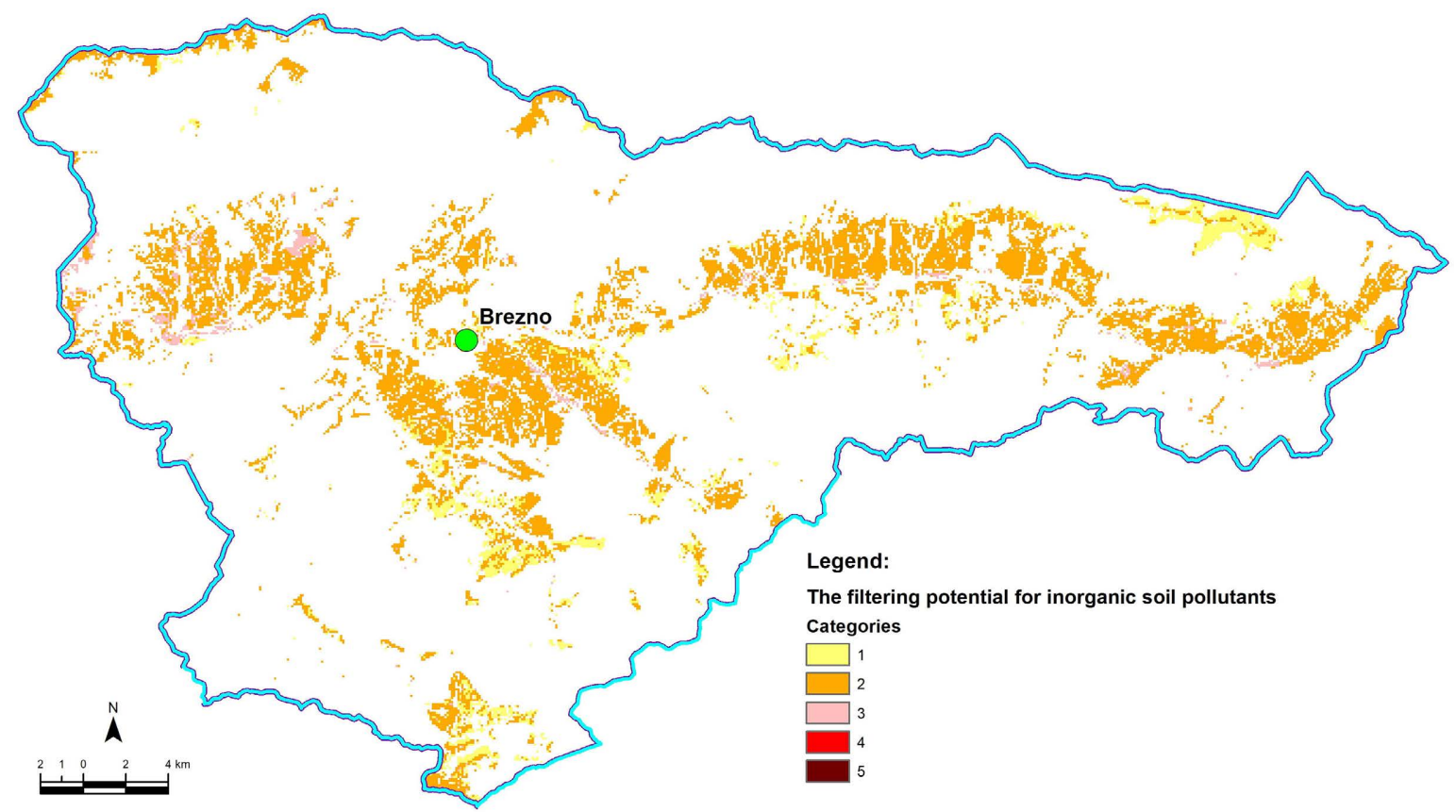

Figure 3. The filtering potential for inorganic soil pollutants in Brezno region (authors: Makovníková J. and Pálka B.; green dot means localization of capital city of the region).

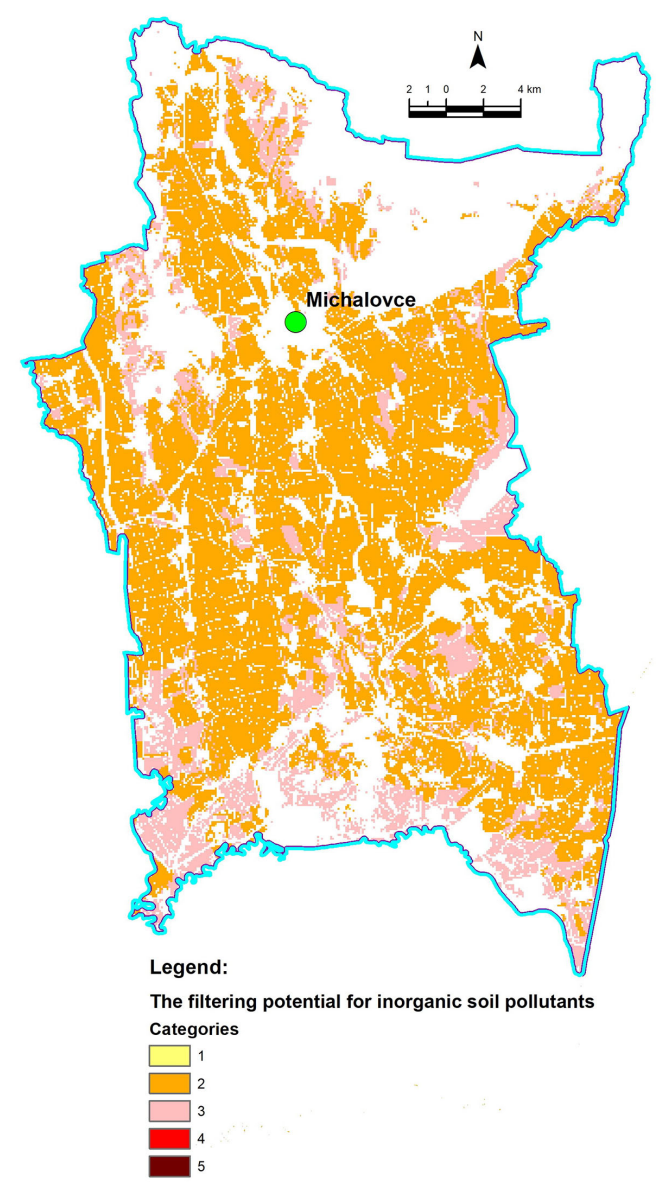

Figure 4. The filtering potential for inorganic soil pollutants in Michalovce region (authors: Makovníková J. and Pálka B.; green dot means localization of capital city of the region). 


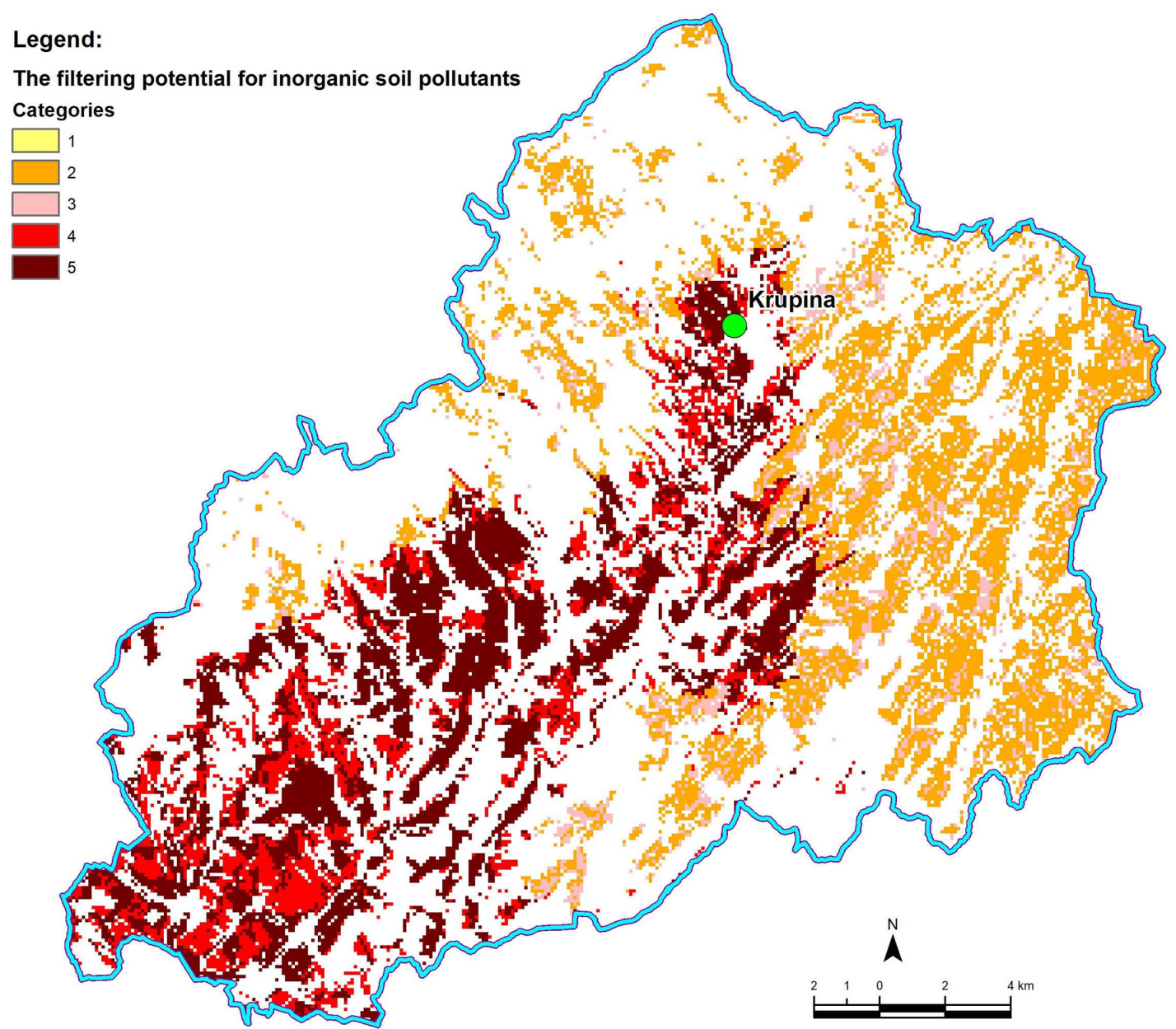

Figure 5. The filtering potential for inorganic soil pollutants in Krupina region (authors: Makovníková J. and Pálka B.; green dot means localization of capital city of the region).

Distribution of the categories of filtration potential in \% of used agricultural land in the model regions are as follows:

Very low potential Brezno $>$ Michalovce $=$ Krupina $=$ Pieštany

Low potential Michalovce $>$ Brezno $>$ Krupina $>$ Pieštany

Medium potential Michalovce $>$ Brezno $>$ Krupina $>$ Pieštany

High potential Krupina $>$ Pieštany $>$ Michalovce $=$ Brezno

Very high potential Pieštany $>$ Krupina $>$ Michalovce $=$ Brezno

Differences can be seen between all model regions. Agroecosystems in the Pieštany region have a very high filtration potential (immobilization of inorganic pollutants) (Table 1, Figure 2). There are a high proportion of very productive arable lands in the Pieštany region. Mostly ecosystems of arable land with soils developed on loess, located in the Danube and the Eastern Slovak Lowland without any anthropogenic and geochemical deposition, are the main contributors. These ecosystems which are located on Chernozems and Cutanic Luvisols (on soils characterized by high carbonate content with a neutral or slightly alkaline $\mathrm{pH}$ value and with high organic matter content; Kobza et al., 2014) have the highest filtering potential. These soils belong to soils with optimal soil parame- 
ters with respect to the filtering ecosystem service. Ecosystems of low filtering potential (Table 1) are predominantly located on Fluvisols (along Hron River in Brezno region, Figure 3, and Laborec and Ondava River in Michalovce region, Figure 4). The low filtering potential of these ecosystems is mainly due by a higher content of risk elements in alluvial sediments (caused by anthropogenic deposition as well as the low potential of soil sorbents-low soil $\mathrm{pH}$ value, low carbonate content and low content of lower quality organic substances; Makovniková, 2001; Makovniková et al., 2007; Donisa et al., 2003; Boruvka \& Drabek, 2004; Makovniková \& Barančíková, 2009). The mountain soils on grassland (Podzols, Dystric Cambisols located predominantly in Brezno region, Figure 3) are also strongly involved in the very low and low category of filtering potential. These soils are developed on substrates with higher content of risk elements (geochemical anomalies; Čurlík, 2011) due to predominantly parent material. Ecosystems of permanent grasslands are mostly at higher altitudes as well as on higher slopes, on soils with low sorption potential developed on substrates with higher content of risk elements (Makovniková et al., 2007; Kobza et al. 2014). Our results showed that the high risk of inorganic contaminants is inherent in soils with low content and quality of soil organic matter, low $\mathrm{pH}$ value and high concentration of contaminants.

In the Krupina region (Figure 5), there are higher represented agroecosystems with very high and high filtration service, especially brown earth, soils whose soil reaction value ranges from neutral to weakly alkaline area (Kobza et al., 2014) with high content of organic matter in surface horizon (Barančíková \& Makovníková, 2003), which have the highest potential for soil cleaning. The higher representation of the low potential category in this region is due to combination of geochemical and anthropogenic contamination. Anthropic contamination is caused by intensive mining and processing of various ores in the region.

It is important to note that agroecosystems are significantly affected by human activity and are not able to provide ecosystem services without any human intervention (human and social capital). Based on the correlation analysis (Table 2), we can state that climate and altitude belong to the attributes with a statistically significant impact on the potential of this regulatory service. In the case of arable lands, the influence of climate on the filtration service is more pronounced in comparison with the agroecosystem of grasslands, where the influence of altitude is more pronounced. Climate, together with the substrate, is also one of the main factors that also influence the genesis of the soil formation process (Bujnovský et al., 2011; Kanianska et al., 2016).

Table 2. Correlation coefficients between filtering potential for agroecosystem and climate, and altitude.

\begin{tabular}{cccc}
\hline Correlation coefficient & Agricultural land & Arable land & Grassland \\
\hline climate & $-0.72^{\star * *}$ & $-0.78^{\star * *}$ & $-0.66^{* * *}$ \\
altitude & $-0.36^{\star *}$ & $-0.39^{\star *}$ & $-0.44^{\star * *}$ \\
\hline
\end{tabular}

Significance labels: ${ }^{* *} p<0.001,{ }^{* *} p<0.01,{ }^{\star} p<0.05$, ns: non significant. 
The provision of ecosystem service depends on biophysical processes in ecosystem, land use and climate (Burkhard et al., 2014; Smith et al., 2013; Makovniková et al., 2007), therefore the distribution of this service is geographically different. The greatest differences among regions were found in relation to climatic conditions (Table 2), land use type and diversity of soil types. Greiner et al. (2017) confirmed the significant contribution of soils to ecosystem services.

\section{Conclusion}

Our results showed that climate has the most significant impact on the potential of filtration agroecosystem services. The warm, dry, lowland region has a higher potential for pollutant filtration than the moderately warm to cold region. These results are consistent with the location of the soil, its properties, processes and functions in the concept of agro-ecosystem services.

The proposed mapping system can be used to monitor changes in regulating ecosystem services due to land use, spatial planning as well as for the implementation of the evaluation of the potential of natural capital services within socio-economic planning of regions and country. The mapping of ecosystem services and their integration into regional decision making including the optimization of ecosystem services potential can contribute to the sustainable use of ecosystems.

\section{Acknowledgements}

This publication was supported by the Operational program Integrated Infrastructure within the project: Sustainable smart farming systems taking into account the future challenges 313011 W112, co-financed by the European Regional Development Fund and the Slovak Research and Development via contract No. APVV-18-0035 "Valuing ecosystem services of natural capital as a tool for assessing the socio-economic potential of the area".

\section{Conflicts of Interest}

The authors declare no conflicts of interest regarding the publication of this paper.

\section{References}

Ahmad, W., Alharthy, R. D., Zubair, M., Ahmed, M., Hameed, A., \& Rafique, S. (2021). Toxic and Heavy Metals Contamination Assessment in Soil and Water to Evaluate Human Health Risk. Scientific Reports, 11, Article No. 17006. https://doi.org/10.1038/s41598-021-94616-4

Alam, M., Dupra, J., \& Messier, C. H. (2016). A Framework towards a Composite Indicator for Urban Ecosystem Services. Ecological Indicators, 60, 38-44. https://doi.org/10.1016/j.ecolind.2015.05.035

Barančíková, G., \& Makovníková, J. (2003). The Influence of Humic Acid Quality on the Sorption and Mobility of Heavy Metals. Plant, Soil and Environment, 49, 565-571. https://doi.org/10.17221/4195-PSE 
Borûvka, L. \& Drábek, O. (2004). Heavy Metals Distribution between Fractions of Humic Substances in Heavily Polluted Soils. Plant, Soil and Environment, 50, 339-345. https://doi.org/10.17221/4041-PSE

Bujnovský, R., Vilček, J., Blaas, G., Skalský, R., Barančíková, G., Makovníková, J., Balkovič, J., \& Pálka, B. (2011). Evaluation of Soil Capacities and Effects from its Use (in Slovak language). Soil Science and Conservation Research Institute.

Burkhard, B., Kroll, F., Müller, F., \& Windhorst, W. (2009). Landscapes` Capacities to Provide Ecosystem Services-A Concept for Land-Cover Based Assessments. Landscape Online, 15, 1-22.

Burkhard, B., Kandziorai, M. S., \& Müller, F. (2014). Ecosystem Service Potentials, Flows and Demands-Concepts for Spatial Localisation, Indication and Quantification. Landscape Online, 34, 1-32.

https://landscape-online.org/index.php/lo/article/view/LO.201434/42

Burkhard, B., \& Maes, J. (2017). Mapping Ecosystem Services. Advanced Books. https://doi.org/10.3897/ab.e12837

Campo, A. (2017). Soil Contamination. Scitus Academics LLC.

Čurlík, J. (2011). Potentially Toxic Trace Elements and Their Distribution in Slovak Soils (in Slovak Language). Comenius University-Faculty of Natural Sciences.

Dendoncker, N., Boeraeve, F., Crouzat, E., Dufręne, M., König, A., \& Barnaud, C. (2018). How Can Integrated Valuation of Ecosystem Services Help Understanding and Steering Agroecological Transitions? Ecology and Society, 23, 12 p.

Dominati, E. J., Patterson, M., \& Mackay, A. (2010). A Framework for Classifying and Quantifying the Natural Capital and Ecosystem Services of Soils. Ecological Economics, 69, 1858-1868. https://doi.org/10.1016/j.ecolecon.2010.05.002

Dominati, E. J. (2013). Natural Capital and Ecosystem Services of Soils. In J. R. Dymond (Ed.), Ecosystem Services in New Zealand-Conditions and Trends (pp. 132-142). Manaaki Whenua Press.

Donisa, C., Mocanu, R., \& Steinnes, E. (2003). Distribution of Some Major and Minor Elements between Fulvic and Humic Fractions in Natural Soils. Geoderma, 111, 75-84. https://doi.org/10.1016/S0016-7061(02)00254-9

Greiner, L., Keller, A., Gret-Regamey, A., \& Papritz, A. (2017). Soil Function Assessment: Review of Methods for Quantifying the Contributions of Soils to Ecosystem Services. Land Use Policy, 69, 224-237. https://doi.org/10.1016/j.landusepol.2017.06.025

Houšková, B., Bušo, R., \& Makovníková, J. (2021). Contribution of Good Agricultural Practices to Soil Biodiversity. Open Journal of Ecology, 11, 75-85. https://doi.org/10.4236/oje.2021.111007

Kanianska, R., Jadudová, J., Makovníková, J., Kizeková, M., \& Tomaškin, J. (2016). Ecosystem Services (in Slovak Language). Belianum.

Kobza, J., Barančíková, G., Dodok, R., Hrivňáková, K., Makovníková, J., Pálka, B., Pavlenda, P., Schlosserová, J., Styk, J., \& Širáň, M. (2014). Soil Monitoring in the Slovak Republic. Current State and Development of Monitored Soil Properties as a Basis for Their Protection and Further Use (2007-2012) (in Slovak Language). NAFC-Soil Science and Conservation Research Institute.

MEA-Millennium Ecosystem Assessment (2005). Ecosystems and Human Well-Being: Our Human Planet: Summary for Decision Makers. The Millennium Ecosystem Assessment Series. Island Press.

Maes, J, Burkhard, B., \& Geneletti, D. (2018). Ecosystem Services Are Inclusive and Deliver Multiple Values. A Comment on the Concept of Nature's Contributions to People. 
One Ecosystem, 3, e24720. https://doi.org/10.3897/oneeco.3.e24720

Makovníková, J., Barančíková, G., \& Pálka, B. (2007). Approach to the Assessment of Transport Risk of Inorganic Pollutants Based on the Immobilisation Capability of Soil. Plant, Soil and Environment, 53, 365-373. https://doi.org/10.17221/2215-PSE

Makovníková, J., \& Barančíková, G. (2009). Assessment of Transport Risk of Cadmium and Lead on the Basis of Immobilisation Capability of Soil. Soil and Water Research, 4, 10-16. https://doi.org/10.17221/31/2008-SWR

Makovníková, J. (2001). Distribution of Cd and Pb in Main Soil Types of Slovakia. Agriculture, 47, 903-912.

Naidu, R., McLaughlin, M. J., Roger, S., Oliver, D. P., \& Kookana, R. S. (1996). Contaminants and the Soil Environment in the Australia-Pacific Region. In R. Naidu, M. J. McLaughlin, S. Roger, D. P. Oliver, \& R. S. Kookana (Eds.), Proceedings of the 1st Australia-Pacific Conference. Kluwer Academic. https://doi.org/10.1007/978-94-009-1626-5

Ryzhenko, N. O., \& Kavetsky, S. V. (2015). Heavy Metals (Cd, Pb, Zn, and Cu) Uptake by Spring Barley in Polluted Soils. Polish Journal of Soil Science, 48, 11-129. https://doi.org/10.17951/pjss.2015.48.1.111

Smith, P., Ashmore, M. R., Black, H. I. J., Burgess, P. J., Evans, C. D., Quine, T. A., Thomson, A. M., Hicks, K., \& Orr, H. G. (2013). Review: The Role of Ecosystems and Their Management in Regulating Climate, and Soil, Water and Air Quality. Journal of Applied Ecology, 50, 812-829. https://doi.org/10.1111/1365-2664.12016

Yong, R. N., Mohamed, A. M. O., \& Warkentin, B. P. (1992). Principles of Contaminant Transport in Soils. Elsevier. 